\title{
Penerapan Evaluasi Pembelajaran Penjas Secara Daring Tingkat SMP Selama Masa Pandemi Covid-19
}

\section{Application of Evaluation of Physical Education Learning Online for Junior High School Level During the Covid-19 Pandemic}

\author{
Nancy Trisari Schiff ${ }^{1}$, Gita Febria Friskawati ${ }^{2}$, Heru Sulistiadinata ${ }^{3}$, Vicki \\ Ahmad Karisman ${ }^{4}$ \\ 1,2,3,4 Program studiPJKR, STKIP Pasundan, Jalan Permana No. 32B Kota Cimahi, Jawa Barat, \\ 40553, Indonesia
}

\begin{abstract}
Abstrak
Tujuan penelitian ini adalah untuk mengetahui bagaimana penerapan evaluasi pembelajaran pendidikan jasmani yang dilakukan oleh guru tingkat SMP selama pandemi yang mencakup Model, Jenis, Cara dan Media yang digunakan selama pandemi covid-19. Metode yang digunakan ialah Deskriptif kuantitatif dengan bentuk Survey. Populasi pada penelitian ini adalah 20 orang tenaga pendidik di kota Bandung bagian wilayah Bandung Barat. Instrumen yang digunakan ialah berupa angket kuesioner yang dibuat melalui Google Form dan disebarkan dengan bantuan Whatsapp Group. Hasil analisis dari keseluruhan indikator dalam penerapan evaluasi pembelajaran penjas secara daring dimasa covid-19 ini menunjukan bahwa 13\% memiliki kategori tinggi, $67 \%$ memiliki kategori sedang, dan 20\% memiliki kategori rendah. Melihat hasil persentase frekuensi pada kategori sedang memilki posisi teratas dibanding kedua kategori lainnya, hal ini menunjukan bahwa penerapan evaluasi pembelajaran penjas secara daring yang mencakup model, jenis, cara, dan media adalah sedang. Dan secara keseluruhan dari empat indikator menunjukan penerapan evaluasi pembelajaran penjas tingkat SMP secara daring memiliki kategori sedang, dengan penjabaran $13 \%$ dari 2 responden memiliki kategori tinggi, 67\% dari 10 responden memiliki kategori sedang, dan 20\% dari 3 responden memiliki kategori rendah.
\end{abstract}

Kata kunci: Evaluasi Pembelajaran, Penjas, Daring

\begin{abstract}
The purpose of this study was to find out how the evaluation of physical education learning carried out by junior high school level teachers during the pandemic included models, types, methods and media used during the covid-19 pandemic. The method used is descriptive quantitative in the form of a survey. The population in this study were 20 educators in the city of Bandung in the West Bandung area. The instrument used is in the form of a questionnaire made through Google Form and distributed with the help of Whatsapp Group. The results of the analysis of all indicators in the application of online physical education learning evaluation during the Covid-19 period showed that $13 \%$ had a high category, $67 \%$ had a medium category, and $20 \%$ had a low category. Looking at the results of the percentage of frequency in the medium category having the top position compared to the other two categories, this shows that the application of online physical education learning evaluation which includes models, types, methods, and media is moderate. And overall, from the four indicators, it shows that the implementation of online evaluation of physical education learning at the junior high school level has a medium category, with the explanation that $13 \%$ of 2 respondents have a high category,
\end{abstract}

Correspondence author: Nancy Trisari Schiff/ Gita Febria Friskawati/Heru Sulistiadinata/Vicki Ahmad Karisman. STKIP Pasundan cimahi, Indonesia.

Email: 
$67 \%$ of 10 respondents have a medium category, and $20 \%$ of 3 respondents have a low category.

Keywords: Learning Evaluation, Physical Education, Online

\section{PENDAHULUAN}

Pendidikan jasmani sebagai integral dari pendidikan memiliki tantangan yang semakin besar dalam mengimplementasikan nilai-nilai yang terkandung dalam kurikulum rangka pembangunan generasi yang lebih baik. Pendidikan jasmani merupakan pendidikan yang mengaktualisasikan potensi-potensi manusia berupa sikap, tindak dan karya dalam sebuah satu kesatuan utuh dalam diri manusia (Budiman et al., 2018). Pendidikan jasmani memiliki dua keuntungan utama, yaitu keuntungan fisik dan edukasi. Keuntungan fisik meliputu: kebugaran, keterampilan gerak, dan kebiasaan melakukan aktivitas fisik (gaya hidup aktif). Sedangkan keuntungan edukasi meliputi : sosial, afektif dan kognitif menurut (Bailey, 2009). Pendidikan jasmani dapat di definisikan suatu proses pendidikan yang ditunjukkan sebagai untuk mencapai tujuan pendidikan melalui aktivitas gerak (Hasmarita \& Kurnia, 2020).

Dalam proses pembelajaran terdapat dua kegiatan dalam satu waktu dengan pelaku yang berbeda. Pelaku belajar adalah siswa sedangkan pelaku pengajar adalah guru. Kegiatan siswa dan guru berlangsung dalam proses yang bersamaan untuk mencapai tujuan tertentu. (Harjasuganda, 2008). Memperbaiki sistem pembelajaran yang sudah ada. Pandemi Corona Virus Disease (Covid-19) telah menyebar kebanyak negara dan wilayah termasuk Indonesia. Covid-19 ditularkan melalui kontak langsung dengan cairan nafas yang dihasilkan melalui batuk dan bersin orang terinfeksi dan atau saat menyentuh permukaan yang terkontaminasi virus, kemudian mnyentuh area wajah (misal: mata, hidung, dan mulut) World Healty Organistation 2020. Perlindungan terhadap anak-anak dan fasilitas pendidikan menjadi hal yang sangat penting. Diperlukan tindakan untuk mencegah potensi penularan dan penyebaran Covid-19 di lingkungan sekolah dengan tetap memberikan kesempatan siswa untuk belajar, dan membangun jiwa siswa yang lebih peduli serta membangun kemampuan siswa untuk mengatasi dampak sekunder dari penyakit ini, Modifikasi pembelajaran menjadi salah satu solusi yang tepat untuk dapat melaksanakan pembelajaran penjas diberbagai jenjang pendidikan (Ramadhani, 2021).

Evaluasi merupakan bagian yang tidak dapat dipisahkan dalam proses kegiatan belajar mengajar(Daryanto, 2001). Evaluasi adalah pengumpulan kenyatan secara sistematis untuk menetapkan sejauh mana tingkat perubahan dalam pribadi siswa. Dengan 
demikian salah satu faktor yang penting untuk mencapai tujuan pendidikan adalah proses pembelajaran yang dilakukan, sedangkan salah satu faktor penting untuk efekktivitas pembelajaran adalah faktor evaluasi baik terhadap proses maupun hasil pembelajaran. Secara harfiah kata evaluasi berasal dari bahasa inggris evaluation, dalam bahasa Indonesia berati penilaian. Akar katanya adalah value yang berarti nilai. Dengan demikian secara harfiah evaluasi pendidikan dapat diartikan sebagai penilaian dalam pendidikan atau penilaian mengenai hal-hal yang berkaitan dengan kegiatan pendidikan (H.M, 2010).

Tujuan evaluasi adalah untuk menentukan kualitas daripada sesuatu, terutama yang berkenaan dengan nilai dan arti. Dalam (Arifin, 2015). Pemberian nilai dilakukan apabila seorang evaluator memberikan pertimbangannya mengenai evaluan tanpa menghubungkannya dengan sesuatu yang bersifat dari luar. Jadi pertimbangan yang diberikan sepenuhnya berdasarkan apa evaluan itu sendiri, sedangkan arti, berhubungan dengan posisi dan peranan evaluan dalam suatu konteks tertentu. Evaluasi untuk suatu tujuan tertentu penting, tetapi ada kemungkinana tidak bermanfaat untuk tujuan lain, oleh karena itu, seorang guru harus mengenal beberapa macam tujuan evaluasi dan syaratsyarat yang harus dipenuhi agar mereka dapat merencanakan dan melakukan evaluasi dengan bijak dan tepat. Evaluasi yang baik harus mempunyai syarat seperti berikut : 1) Valid, 2) Andal, 3) Objektif, 4) Seimbang, 5) Membedakan, 6) Norma, 7) Fair, dan 8) Praktis (Thomas, n.d.)

Disini terlihat jelas bahwa tugas guru sangat dominan, sedangkan siswa hanya berada pada pihak yang pasif dan siap menerima segala bentuk sesuatu yang diberikan. Pandangan seperti ini sudah tidak sesuai lagi dengan kemajuan berpikir dan kemajuan jaman. Pandangan ini harus disingkirkan dan digantikan dengan filosofi yang lebih manusiawi. Dengan menggunakan istilah pembelajaran terasa ada kemampuan siswa untuk belajar dan kemampuan ini akan terwujud apabila dibantu dan dibimbing oleh guru. Oleh karena itu penegrtian pembelajaran adalah usaha sadar guru untuk membantu siswa atau peserta didik agar mereka dapat 181 sesuai dengan kebutuhan dan minatnya (MKDK, 2001).

Pembelajaran yang sering disebut juga dengan dua kata berbeda yaitu belajar dan mengajar sebagai terjemahan dari istilah "intructional". Belajar adalah suatu proses yang ditandai dengan adanya perubahan pada diri seseorang hal ini sesuai dengan pendapat dalam (Agustanico Dwi Muryadi, 2005) bahwa perubahan adalah sebagai hasil proses belajar yang dapat ditunjukan dengan berbagai bentuk seperti perubahan pengetahuan, kecakapan dan kemampuan, daya reaksi, penerimaan, dan lain-lain dari aspek individu. 
Evaluasi pendidikan adalah kegiatan menilai yang terjadi dalam kegiatan pendidikan. Guru ataupun pengelola pengajaran mengadakan penilaian dengan maksud melihat apakah usaha yang dilakukan melalui pengajaran sudah mencapai tujuannya atau belum. Perencanaan berasal dari kata rencana yang mengandung arti rancangan, konsep, cerita, atau program. Sehubungan dengan itu perencanaan dapat diartikan sebagai proses menyusunan program secara akademis yang dapat dipertanggungjawabkan secara realistis agar dapat dilaksanakan dan dapat mencapai tujuan secara efektif dan efisien. Perencanaan ini bersifat umum, bisa berlaku hampir pada semua kegiatan termasuk perencanaan penyelenggaraan pendidikan jasmani disekolah. Khusus untuk pendidikan penataan dalam proses pembuatan perencanaan pengajaran pendidikan jasmani nampak lebih penting mengingat lingkungan yang pembelajaran yang unik yaitu di area bebas atau lingkungan terbuka (Widiyatmoko \& Hudah, 2017).

Dalam melaksanakan pengajaran pendidikan jasmani yang diutamakan adalah partisipasi dari siswa yaitu siswa dituntut untuk banyak bergerak dan berkarya. Pelaksanaan adalah proses, cara, pembuatan, pengaplikasian, sutu rancangan dan pengambilan keputusan. Salah satu prinsip penting dalam pendidikan jasmani adalah partisipasi siswa secara penuh dan merata, karna pendidikan jasmani harus memperhatikan kepentingan siswa dengan memperhatikan perbedaan kemampuannya. Seperangkat kemampuan siswa itu antara lain kemampuan psikomotorik, afektif dan kognitif (Prilanji, F.B., Simanjutak, V.G., Haetami, 2019). Evaluasi mikro sering digunakan di tingkat kelas, khususnya untuk mengetahui pencapaian belajar peserta didik. Pencapaian belajar ini bukan hanya yang bersifat kognitif saja, tetapi mencakup semua potensi yang ada pada peserta didik. Jadi sasaran evaluasi mikro adalah program pembelajaran dikelas dan yang bertanggung jawabnya adalah guru untuk sekolah dan dosen untuk perguruan tinggi (Mardapi, 1999).

Munculnya wabah virus Covid 19 mengharuskan proses pembelajaran senam dilakukan secara daring (Online) menyusul terbitnya Surat Edaran Menteri Pendidikan dan Kebudayaan No.36962/MPK.A/HK/2020 terkait Pembelajaran Secara Daring dan Bekerja dari Rumah Dalam Rangka Pencegahan Penyebaran Corona Virus Disease 2019 (COVID 19). Merujuk aturan menteri Pendidikan dan Kebudayaan sebagai leading sector bidang pendidikan, sistem pembelajaran daring menjadi langkah alternatif dalam proses maupun evaluasi pembelajaran. Metode pembelajaran daring dengan menerapkan modifikasi materi pembelajaran dapat membantu pengajar dan peserta didik selama pandemi Covid 19. Modifikasi pembelajaran menjadi salah satu solusi yang tepat untuk dapat melaksanakan pembelajaran penjas diberbagai jenjang pendidikan (D. R. Budi et 
al., n.d.). Hal ini didukung dengan perkembangan teknologi yang tidak terbatas pada revolusi industry 4.0 saat ini. Pembelajaran online secara efektif untuk melaksanakan pembelajaran meskipun pendidik dan peserta didik berada di tempat yang berbeda dalam (Herliandry et al., 2020) Ini mampu menyelesaikan permasalahan keterlambatan peserta didik untuk memperoleh ilmu pengetahuan.

Berdasarkan hasil pengamatan yang dilakukan penulis di beberapa sekolah di kota Bandung, diperoleh informasi bahwa masih terdapat guru penjas yang melakukan evaluasi dengan standarnya masing-masing. Dengan kata lain guru membuat perangkat evaluasi tanpa mengkaitkan dengan silabus yang telah disepakati bersama. Bahkan ada juga yang belum memasukan aspek kognitif dalam proses evaluasinya. Guru tersebut masih beranggapan bahwa yang bisa dilakukan saat praktek hanya evaluasi aspek afektif dan psikomotor saja, sedangkan evaluasi kognitif hanya bisa dilakukan dalam pemebelajaran teori di kelas. Selain itu dalam melakukan evaluasi guru juga masih belum objektif, hal ini ditunjukkan dengan masih adanya istilah "nilai kemanusiaan" dalam pengambilan penilaian. Berdasarkan permasalahan tersebut, guru harus melaksankan evaluasi pembelajaran penjas sebagai bentuk pertanggungjawaban secara realistis dari hasil proses pembelajaran penjas agar tujuan pembelajaran penjas dapat dicapai secara efektif dan efisien.

\section{METODE}

Metode penelitian yang digunakan dalam penelitian ini adalah penelitian survei. Menurut (Maksum, 2012) penelitian survei adalah "penelitian yang mengambil sampel dari satu populasi dan menggunakan kuesioner sebagai alat pengumpulan data yang pokok". Dalam (Burhan Bungin, 2005) "survey adalah metode pengumpulan data dengan menggunakan instrumen untuk meminta tanggapan dari responden tentang sampel”. Disimpulkan bahwa penelitian survei adalah pengumpulan data yang digunakan untuk mendapatkan informasi dalam waktu yang sama untuk menjawab pertanyaan dari suatu persoalan tertentu.

\section{Populasi}

Populasi dapat didefinisikan sebagai suatu kumpulan subjek, variabel, konsep, atau fenomena. Kita dapat meneliti setiap anggota populasi untuk mengetahui sifat populasi yang bersangkutan. Sehingga populasi dalam penelitian ini adalah 15 tenaga pendidik (guru) penjas tingkat SMP di Wilayah Bandung bagian Barat. 


\section{Sampel}

Teknik Sampling yang dipilih yaitu dengan Sampling Jenuh. Sehingga Sampel pada penelitian ini berjumlah 15 orang.

\section{Instrumen}

Instrument penelitian adalah suatu alat yang digunakan mengukur fenomena alam maupun sosial yang diamati. Alat yang digunakan oleh peneliti sebagai alat pengumpulan data adalah angket atau kuesioner yang diberikan langsung oleh responden, berupa pertanyaan tertulis yang bertujuan untuk menggali informasi atau pemahaman mengenai hal yang diketahui dan dilakukan oleh responden tentang pengetahuan pentingnya penerapan evaluasi dalam pembelajaran penjas secara daring (Sugiyono, 2012). Instrument penelitian dapat digunakan apabila telah memenuhi uji yang Reliabilitas dan Validitas sehingga kebenarannya telc ${ }^{2}$ ㅅ:.: sebelumnya. Yang akan dilakukan pada penelitian ini adalah dengan angket seI 184 Ig dikatakan angket merupakan serangkaian atau daftar pertanyaan yang disusun secara sistematis, kemudian dikirim untuk diisi oleh responden dan menggunakan sekala Likert. Skala likert adalah skala pengukuran yang dikembangkan oleh Likert (1932). Skala likert mempunyai empat atau lebih butir-butir pertanyaan yang dikombinasikan sehingga membentuk sebuah skor/nilai titik pilihan pada setiap butir pertanyaan yaitu sangat setuju, setuju, tidak memutuskan, tidak setuju, dan sangat tidak setuju (Budiaji, 2013).

Dalam melakukan evaluasi dan penilaian hasil belajar peserta didik pada jenjang pendidikan dasar dan menengah selalu didasarkan pada prinsip-prinsip evaluasi sebagaimana tercantum dalam Kemendikbud 2013 yaitu Objektif, Terpadu, Ekonomis, Transparan, Akuntabel, dan Edukatif (Misbakhul, 2017)

Metode pembelajaran daring dengan menerapkan modifikasi materi pembelajaran dapat membantu pengajar dan peserta didik selama pandemi Covid 19. Modifikasi pembelajaran menjadi salah satu solusi yang tepat untuk dapat melaksanakan pembelajaran penjas diberbagai jenjang pendidikan (D. R. Budi et al., n.d.). Pembelajaran online secara efektif untuk melaksanakan pembelajaran meskipun pendidik dan peserta didik berada di tempat yang berbeda ini mampu menyelesaikan permasalahan keterlambatan peserta didik untuk memperoleh ilmu pengetahuan. Berbagai platform lainnya seperti aplikasi google (google classroom, google form, google docs, google spreadsheet) dapat dimanfaatkan untuk mendukung transfer pengetahuan yang didukung berbagai teknik diskusi dan lainnya (Mansyur, 2020). 


\section{Analiisa data}

Analisis data adalah proses mengatur urutan data, mengorganisasikannya dalam suatu pola, kategori, dan satuan uraian dasar. Analisis data adalah rangkaian kegiatan penelaahan, pengelompokan, sistematisai, penafsiran, dan verifikasi data agar sebuah fenomena memiliki nilai sosial, akademis dan ilmiah (Istikomah.Siti, n.d.). Sesuai dengan jenis penelitian dan jenis data, Teknik analisis data yang digunakan pada penelitian ini yaitu analisis deskriptif, 185 an program bantu pengolahan data atau angka yaitu SPSS versi 22 dalam melakukan analisis data.

\section{HASIL DAN PEMBAHASAN}

\section{Hasil}

Deskripsi data merupakan gambaran yang digunakan dalam suatu penelitian. Dalam penelitian deskripsi data ini peneliti menggunakan variabel tunggal, dari pengumpulan data hasil jawaban kuesioner responden, dengan jumlah sampel yaitu 15 orang tenaga pendidik (guru) di wilayah Bandung bagian Barat, pengujian dilakukan dengan menggunakan bantuan program Microsoft Excel dan Statistical Program and Service Solution seri 21.0. Berikut ini disajikan deskripsi dari variabel yang diteliti.

Indikator - indikator evaluasi pembelajaran penjas ini dibuat sesuai proses pembelajaran dari aspek penunjangnya. Hasil dari tiap butir soal tersebut kemudian dikelompokan berdasarkan indikator yang telah di tetapkan dalam kisi-kisi kuesioner penerapan evaluasi pembelajaran penjas secara daring. Indikator tersebut meliputi: 1) Model evaluasi, 2) Jenis evaluasi, 3) Cara evaluasi, 4) Media evaluasi.

\section{Model Evaluasi}

Dari analisis yang dilakukan oleh peneliti diperoleh ketentuan untuk skor tertinggi (MAX), skor terendah (MIN), median (M), dan standard devisi (SD). Berikut disajikan tabel serta histogram distribusi frekuensi hasil pengkategorian.

\section{Tabel 1}

\begin{tabular}{ccc}
\multicolumn{3}{c}{ Analisis } \\
\hline No & Anatistiks & Model Evaluasi (CIPP) \\
\hline $\mathbf{1}$ & MAX & 4 \\
& & 1 \\
\hline $\mathbf{2}$ & MIN & \\
\hline $\mathbf{3}$ & MEDIAN & 22,7
\end{tabular}


Vol. 3 No. 2, Oktober 2021, pp. 179-193:

\begin{tabular}{lcc}
\hline $\mathbf{4}$ & $\mathrm{SD}$ & 1,8 \\
\hline $\mathbf{4}$ & $\mathrm{M}-1 \mathrm{SD}$ & 21,0 \\
\hline $\mathbf{5}$ & $\mathrm{M}+1 \mathrm{SD}$ & 24,5 \\
\hline
\end{tabular}

Tabel 2

Distribusi Frekuensi Model Evaluasi (CIPP)

\begin{tabular}{ccccc}
\hline No & Interval & Frekuensi & Presentase & Kategori \\
\hline $\mathbf{1}$ & $\mathrm{X}<21,0$ & 1 & $7 \%$ & RENDAH \\
\hline $\mathbf{2}$ & $21,0<=\mathrm{X}<24,5$ & 11 & $73 \%$ & SEDANG \\
\hline $\mathbf{3}$ & $\mathrm{X}>=24,5$ & 3 & $20 \%$ & TINGGI \\
& & & & \\
\hline & JUMLAH & 15 & $100 \%$ &
\end{tabular}

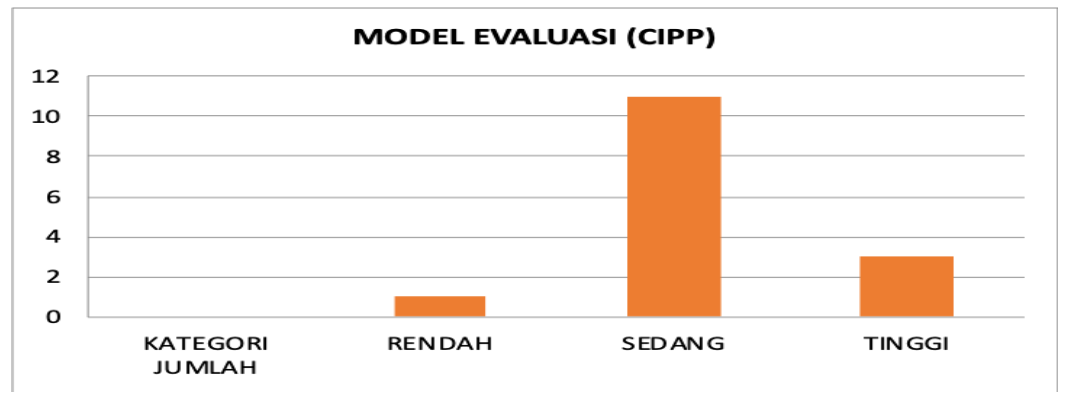

\section{Gambar 1}

Diagram Batang Model Evaluasi (CIPP)

\section{Jenis Evaluasi}

Dari analisis yang dilakukan oleh peneliti diperoleh ketentuan untuk skor tertinggi (MAX), skor terendah (MIN), median (M), dan standard devisi (SD). Berikut disajikan tabel serta histogram distribusi frekuensi hasil pengkategorian 


\section{Tabel 3}

Distribusi Frekuensi Jenis Evaluasi

\begin{tabular}{ccccc}
\hline No & Interval & Frekuensi & Presentase & Kategori \\
\hline $\mathbf{1}$ & $\mathrm{X}<15,1$ & 9 & $60 \%$ & Rendah \\
\hline $\mathbf{2}$ & $15,1<=\mathrm{X} \mathrm{16,0}$ & 6 & $40 \%$ & Sedang \\
\hline $\mathbf{3}$ & $\mathrm{X}>=16,0$ & 0 & & \\
\hline
\end{tabular}

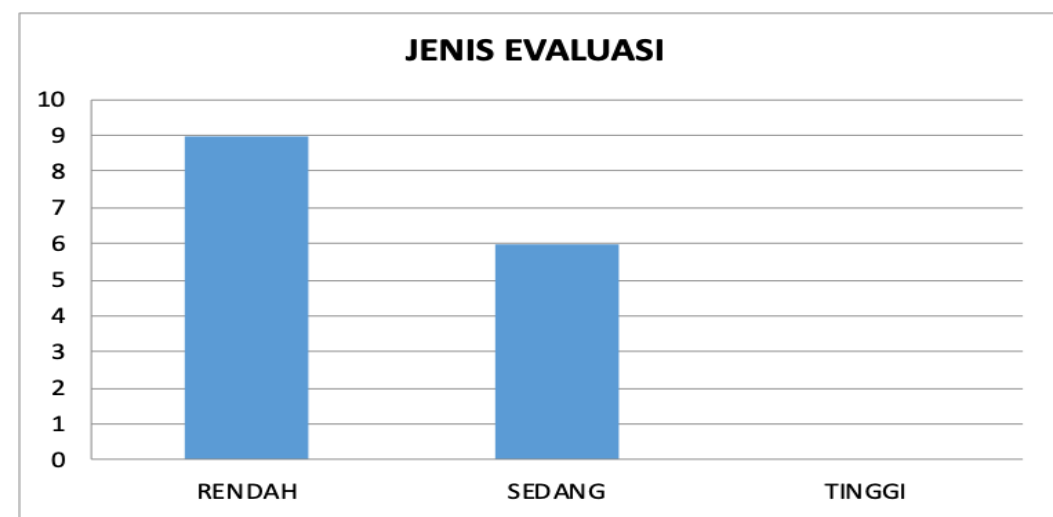

\section{Gambar 1}

Diagram Batang Jenis Evalusi

Berdasarkan tabel dan diagram diatas dapat diketahui Penerapan Evaluasi pembelajaran penjas secara daring pada aspek jenis terdapat 9 responden $(60 \%)$ memiliki kategori rendan, 6 responden (40\%) memiliki kategori sedang, dan tidak ada responden $(0 \%)$ memiliki kategori tinggi.

\section{Cara Evaluasi}

Dari analisis yang dilakukan oleh peneliti diperoleh ketentuan untuk skor tertinggi (MAX), skor terendah (MIN), median (M), dan standard devisi (SD). Berikut disajikan tabel serta histogram distribusi frekuensi hasil pengkategorian. 
Tabel 4

Distribusi Frekuensi Cara Evaluasi

\begin{tabular}{ccccc}
\hline No & Interval & Frekuensi & Presentasi & Kategori \\
\hline $\mathbf{1}$ & $\mathrm{X}<14,4$ & 2 & $14 \%$ & Rendah \\
\hline $\mathbf{2}$ & $14,4<=\mathrm{X} \mathrm{17,5}$ & 11 & $73 \%$ & Sedang \\
\hline $\mathbf{3}$ & $\mathrm{X}>=17,5$ & 2 & & Tinggi \\
\hline
\end{tabular}

Berdasarkan tabel diatas dapat diketahui Penerapan evaluasi pembelajaran secara daring pada aspek cara evaluasi yang digunakan 2 responden (14\%) memiliki kategori rendah, 11 responden (73\%) memiliki kategori sedang, dan 2 responden (13\%) memiliki kategori tinggi.

\section{Media Evaluasi}

Dari analisis yang dilakukan oleh peneliti diperoleh ketentuan untuk skor tertinggi (MAX), skor terendah (MIN), median (M), dan standard devisi (SD). Berikut disajikan tabel serta histogram distribusi frekuensi hasil pengkategorian.

\section{Tabel 5}

Distribusi Frekuensi Media Evaluasi

\begin{tabular}{lllll}
\hline No & Interval & Frekuensi & Persentase & Kategori \\
\hline $\mathbf{1}$ & $\mathrm{X}<19,4$ & 4 & $27 \%$ & Rendah \\
\hline $\mathbf{2}$ & $19,4<=\mathrm{X} 20,5$ & 2 & & \\
\hline $\mathbf{3}$ & $\mathrm{X}>=20,5$ & 9 & & Sedang \\
\hline
\end{tabular}

Berdasarkan data diatas diketahui penerapan evaluasi pemebelajaran penjas secara daring dilihat dari aspek media 4 responden (27\%) memiliki kategori rendah, 2 responden (13\%) memiliki kategori sedang, dan 9 responden (60\%) memiliki kategori tinggi.

Dari anlisis yang dilakukan berdasarkan kriteria indikator keseluruhan penelitian yaitu penerapan evaluasi pembelajaran penjas saat pembelajaran daring pada tingkat SMP 
di wilayah Bandung bagian Barat adalah skor tertinggi 82, skor terendah 69, ratarata/mean 74,7, dan standar deviasi (SD) 4,3.

\section{Pembahasan}

Hasil analisis dari keseluruhan indikator dalam penerapan evaluasi pembelajaran penjas secara daring dimasa covid-19 ini menunjukan bahwa 13\% memiliki kategori tinggi, 67\% memiliki kategori sedang, dan 20\% memiliki kategori rendah. Melihat hasil persentase frekuensi pada kategori sedang memilki posisi teratas dibanding kedua kategori lainnya, hal ini menunjukan bahwa penerapan evaluasi pembelajaran penjas secara daring yang mencakup model, jenis, cara, dan media adalah sedang.

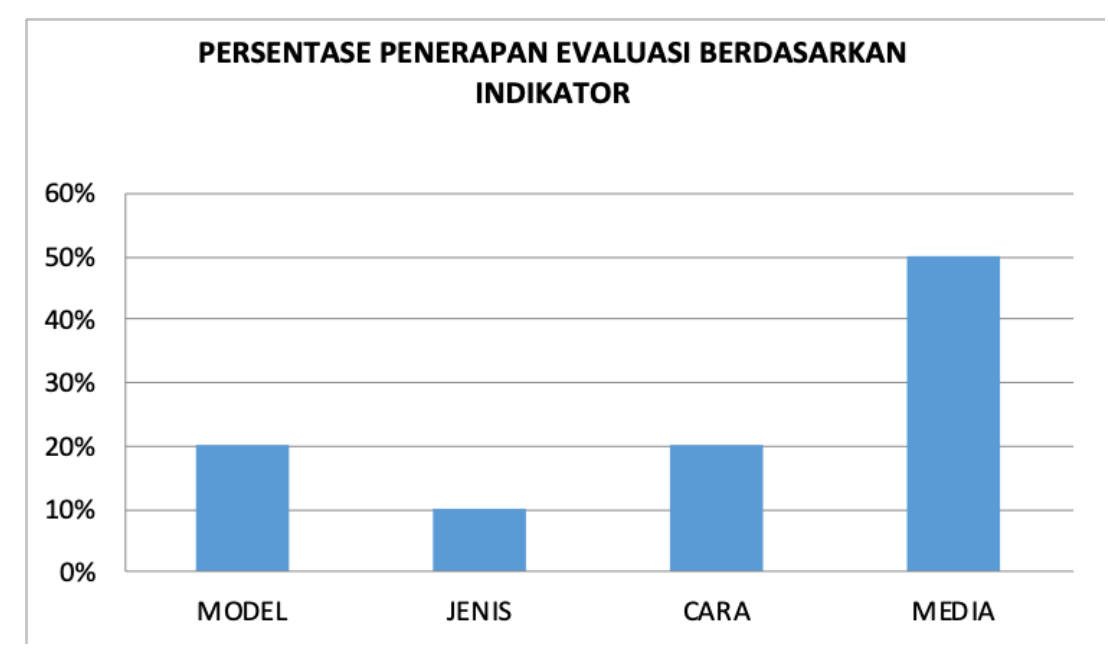

Gambar 3

Hasil Presentase Setiap Indikator

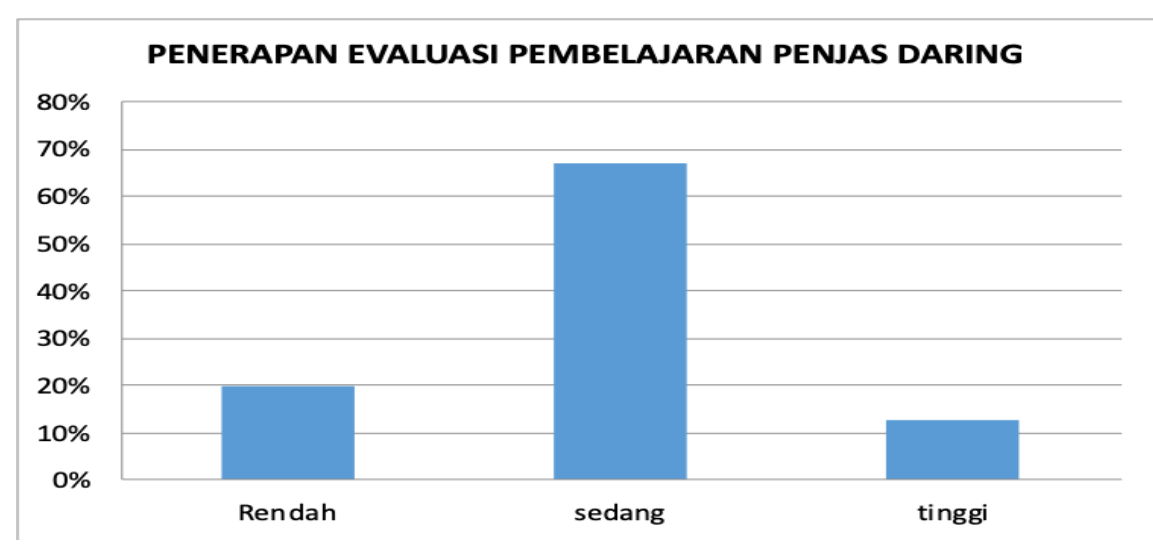

Gambar 4.

Hasil Presentase Keseluruhan Indikator Penerapan Evaluasi Pembelajaran Penjas Secara Daring 
Dapat dikemukakan dengan bahasa yang jelas, bahwa hasil analisis data untuk menjawab pertanyaan penelitian termasuk teori, fakta, opini berdasarkan literature penelitian terdahulu yang mendukung penelitian ini bertujuan untuk mengetahui seberapa besar penerapan evaluasi pembelajaran penjas tingkat SMP di wilayah Bandung bagian Barat yang mencakup aspek Model, Media, Jenis, dan Cara yang dilakukan oleh guru kepada siswa.

Dari hasil penelitian diketahui evaluasi pembelajaran dapat dilakukan dengan berbagai cara termasuk aspek penunjangnya seperti teori yang dikatakan dalam buku sudijono. Berdasarkan hasil analisis data menjelaskan bahwa media yang digunakan dalam penerapan evaluasi pembelajaran penjas dapat menunjang keberlangsungan evaluasi pembelajaran penjas secara daring ini. Membuktikan bahwa guru melakukan penerapan evaluasi pembelajaran sebagai proses evaluasi pembelajaran dimasa covid-19 dan beberapa guru tidak menerapakan evaluasi pembelajaran penjas sesuai dengan aturannya dan hanya menggunakan evaluasi kemanusiaan.

Perbaikan yang dapat dilakukan guru yaitu dengan memodifikasi metode serta materi belajar agar semangat belajar serta motivasi siswa meningkat (B. Budi et al., 2021; Budiman, 2021), sehingga hal tersebut diharapkan bisa meningkatkan hasil belajar siswa dengan cara penerapan evaluai pembelajaran (Rojali et al., 2021). Evaluasi yang telah dilakukan membuktikan bahwa pembelajaran pendidikan jasmani pada masa pandemi COVID-19 di kategorikan kurang, dimana nilai rata rata pada kategori 67,27 (Masa \& Anggara, 2021). Pembelajaran PJOK secara daring ternyata dapat dikategorikan dengan kesimpulan baik dengan prosentase $73.5 \%$, namun aspek produk menjadi terendah. Sehingga aspek produk membutuhkan perbaikan dan pengingkatan serius dalam program pembelajaran PJOK secara daring (Ramadhani, 2021).

Dari beberapa hasil penelitian yang relevan mengambarkan bahwa proses evaluasi pembelajaran penjas harus diterapkan oleh seorang guru PJOK dengan berbagai model, media, jenis ataupun cara dalam mengevaluasi untuk menunjang keberlangsungan proses pembelajaran dengan tujuan meningkatkan kinerja seorang guru serta untuk meningktakan hasil belajar siswa pada pembelajaran PJOK.

\section{KESIMPULAN}

Berdasarkan hasil penelitian diatas yang berjudul "Penerapan Evaluasi Pembelajaran Penjas Tingkat SMP Secara Daring Dimasa Pandemik Covid-19” yang dilaksakan kepada guru penjas di wilayah Bandung bagian Barat. Dapat disimpulkan 
bahwa penerapan evaluasi pembelajaran penjas berdasarkan indikator yang mencakup Model 20\% memiliki kategori sedang, Jenis 20\% memiliki kategori sedang, Cara $10 \%$ memiliki kategori rendah, dan Media 50\% memiliki kategori tinggi.

Kemudian secara keseluruhan dari empat indikator menunjukan penerapan evaluasi pembelajaran penjas tingkat SMP secara daring memiliki kategori sedang, dengan penjabaran $13 \%$ dari 2 responden memiliki kategori tinggi, 67\% dari 10 responden memiliki kategori sedang, dan $20 \%$ dari 3 responden memiliki kategori rendah

\section{DAFTAR PUSTAKA}

Agustanico Dwi Muryadi. (2005). Evaluasi program pembelajaran. 1-16.

Arifin, Z. (2015). Evaluasi Pembelajaran Penulis. In Direktorat Jenderal Pendidikan Islam Kementerian Agama RI.

Bailey, R. (2009). The Educational Benefit Claimed for Physical Education and School Sport. Academic Review, 24, 1-27.

Budi, B., Rouf, T., \& Budiman, A. (2021). Hubungan Motivasi Belajar terhadap Hasil Belajar Passing dalam Sepak Bola. Jpoe, 3(1), 42-49. https://doi.org/10.37742/jpoe.v3i1.114

Budi, D. R., Penjas, J., Kesehatan, F. I., \& Jenderal, U. (n.d.). Evaluasi Pembelajaran Senam di Masa Pandemi Covid 19 Berbasis e-Learning Eldiru. 1-7.

Budiaji, W. (2013). Skala Pengukuran dan Jumlah Respon Skala Likert (The Measurement Scale and The Number of Responses in Likert Scale). Ilmu Pertanian Dan Perikanan, 2(2), 127-133.

Budiman, A. (2021). Implementasi Media Audio Visual terhadap Hasil Tendangan T pada Pencak Silat. Musamus Journal of Physical Education and Sport, 03(02), 5059.

Budiman, A., Juliantine, T., \& Abduljabar, B. (2018). Student's Low Respect and SelfRegulation: is TPSR the Solution. Integrating Science and Technology in Developing Sport and Physical Education. Portugal: SCITEPRES.

Burhan Bungin. (2005). Metodologi Penelitian Kuantitatif. prenanda media group.

Daryanto. (2001). Evaluasi Pendidikan. rineka cipta. 
H.M, S. (2010). Evaluasi Pendidikan Prinsip dan Operasionalnya.

Harjasuganda, D. (2008). Pengembangan Konsep Diri yang Positif pada Siswa SD Sebagai Dampak Penerapan Umpan Balik (Feedback) dalam Proses Pembelajaran Penjas. Dalam Jurnal Pendidikan Dasar Nomor, 9(8), 4-5.

Hasmarita, S., \& Kurnia, D. (2020). Pengaruh gaya mengajar dan kemampuan motorik terhadap hasil belajar forehand drive tenis meja The effect of teaching style and motor ability on learning outcomes of Table tennis forehand drive. 2(2), 185-196.

Herliandry, L. D., Nurhasanah, N., Suban, M. E., \& Kuswanto, H. (2020). Pembelajaran Pada Masa Pandemi Covid-19. JTP - Jurnal Teknologi Pendidikan, 22(1), 65-70. https://doi.org/10.21009/jtp.v22i1.15286

Istikomah.Siti. (n.d.). METODE PENELITIAN EKSPERIMEN. Pp, 46-63.

Maksum, A. (2012). Metodologi Penelitian Dalam olahraga. University Press.

Mansyur, A. R. (2020). Dampak COVID-19 Terhadap Dinamika Pembelajaran Di Indonesia. Education and Learning Journal, I(2), 113. https://doi.org/10.33096/eljour.v1i2.55

Mardapi, D. (1999). Pengukuran, Penelitiaan dan evaluasi. MGMP SLTP.

Masa, K. P., \& Anggara, F. (2021). EVALUASI TINGKAT PEMBELAJARAN PENDIDIKAN PANDEMI COVID-19. 1, 37-45.

Misbakhul. (2017). PELAKSANAAN EVALUASI HASIL BELAJAR SISWA PENDIDIKAN JASMANI OLAHRAGA DAN KESEHATAN (PJOK) DI SEKOLAH MENENGAH ATAS KABUPATEN PURWOREJO.

MKDK, T. (2001). Belajar dan Pembelajaran. IKIP Press.

Prilanji, F.B., Simanjutak, V.G., Haetami, M. (2019). Evaluasi Pembelajaran Penjasorkes. Jurnal Pendidikan Dan Pembelajaran Khatulistiwa, Vol. 8(2), 1-10.

Ramadhani, D. (2021). Evaluasi Pembelajaran PJOK Berbasis Daring Terhadap Tingkat Pemahaman. 7(1), 328-338.

Rojali, W. I., Ngadiman, Budi, D. R., Nurcahyo, P. J., \& Febriani, A. R. (2021). Jurnal MensSana Jurnal MensSana. 5, 182-190. 
Journal of Physical and Outdoor Education, 3 (2) 2021 | 179-193

ISSN : 2721-9992 (Online)

ISSN : 2656-1883 (Print)

Sugiyono. (2012). Statistika Untuk Penelitian. Alfabeta.

Thomas, D. G. (n.d.). No Title.

Widiyatmoko, F. A., \& Hudah, M. (2017). Evaluasi Implementasi Pendidikan Nilai Dalam Pembelajaran Penjas. Jurnal Ilmiah Penjas, 3(2), 44-60. http://ejournal.utp.ac.id/index.php/JIP/article/view/587 